\title{
COMMENT
}

\section{ENVIRONMENTAL ANALYSIS AND REPORTING IN HIGHWAY SYSTEM PLANNING}

The Department of Transportation (DOT) files more environmental impact statements under section 102(2)(C) of the National Environmental Policy Act (NEPA) ${ }^{1}$ than all other agencies of the federal government combined. ${ }^{2}$ Nearly as many impact statements are filed on roads as on all other types of federal projects. ${ }^{3}$ Despite the good faith effort these statistics suggest, the number of court actions brought to enjoin federally funded highway construction projects across the country indicates that there is a substantial clash between perceived environmental values and transportation needs. ${ }^{4}$

Most of these suits are critical, last-minute actions, brought to enjoin imminent construction. The highway planning inadequacies that they disclose, however, may have occurred at an earlier, environmentally more crucial, stage of project development. The Federal Highway Administration (FHWA) presently requires the first environmental impact statement for a project only at the route location stage. ${ }^{5}$ By that time many of the most significant decisions affecting the environment have been made. ${ }^{6}$ Consideration of alternative modes of transportation is no longer feasible. ${ }^{7}$ At that stage only the one project - which may be part of a planned regional highway system, other parts of which may have already been built and still other parts of which may be far in the future - can be considered. In order to achieve a proper balance between environmental needs and highway development, planners must consider projects on both regional and local levels. Environmental analysis and reporting for federally funded highway building must occur at various points in a project's development, beginning at an early stage. This Comment will consider the failings of the present procedures, discuss alternative reporting schemes, and indicate how existing federal statutes may be employed to require environmental analysis and reporting at the system planning stage.

142 U.S.C. $\$ 4332(2)$ (C) (1970).

2 Councir on Environacental Qdatity, Third Annuat Report on the EnvironMIENT 248, fig. 1 (1972) [hereinafter cited as TamRD ANNUAI REPORT].

3 Id. 249, fig. 2.

${ }^{4}$ See Thompson v. Fugate, 347 F. Supp. 120 (E.D. Va. 1972).

5 FHIVA Policy and Procedure Memorandum 90-1, โ $6 \mathrm{~b}$ (Aug. 24, 1971), reprinted in 2 ENv. L. REP. 46106, 46108 (1972).

6 See note 24 infra \& accompanying text.

7 See note 25 infra \& accompanying text. 


\section{The Weaknesses of Present Procedures}

Several discrete steps make up the process by which highway construction projects are programmed for federal money and subsequently guided through various stages of approval by federal officials. ${ }^{8}$ First, as a prerequisite to program approval, the highway must be included in one of several federal-aid highway systems. ${ }^{\circ}$ Then a project must be programmed for the utilization of federal funds available for a given year..$^{10}$ Next, the FHWA must approve the project's route location ${ }^{11}$ and design. ${ }^{12}$ Plans, specifications, and estimates approval must follow. ${ }^{13}$ Finally, the FHWA must give construction approval, called "authorization to proceed."14

For federal aid highways the preparation of environmental impact statements under section $102(2)(C)$ is currently required at the location stage. ${ }^{15} \mathrm{~A}$ draft of this impact statement is circulated among reviewing agencies and made public prior to the location public hearing. ${ }^{16}$ Separate hearings are also provided for in the design phase, ${ }^{17}$ and under

8 See, e.g., Arlington Coalition on Transp. v. Volpe, 458 F.2d 1323 (4th Cir. 1972); Lathan v. Volpe, 455 F.2d 1111 (9th Cir. 1971).

Peterson \& Kennan, The Federal-Aid Highway Program: Administrative Procedures and Judicial Interpretation, 2 ENv. L. REP. 50001 (1972), stands as the most thorough elucidation of this process and reveals the conflicts it breeds between the state's quest for funds and the need for adequate consideration of long-term social and environmental values. See also Macbeth \& Sly, Federal-Aid Highways: Public Participation in the Administrative Stages, 1 Naturat Resources Derense CouncIr, Inc. NewsLetrer, Fall 1971 , at xvii.

9 23 U.S.C. \& 103 (1970).

$10 \mathrm{Id} . \$ 105$.

The exact relationship between program approval and location and design approval may vary. A highway improvement may be programmed in any one of a number of phases from preliminary engineering to paving. Bureau of Public Roads, Policy and Procedure Memorandum 21-1, 13 (Apr. 15, 1958), reprinted in 2 ENv. L. REP. 46507, 46511 (1972). Whether location, design approval, or both appropriately precede or follow program approval would logically seem to depend on the phase in which a highway project is first submitted as part of a state's development program. Nevertheless, to the extent that states generally seek maximum participation of federal aid funds for each undertaking, it can be expected that most construction-oriented projects will be programmed in their early phases and that in most cases program approval will precede location and design approval.

11 FHWA Policy and Procedure Memorandum 20-8, \10d(1), 23 C.F.R. ch. I, pt. 1, app. A, at 15 (1972). Such approval can be given only after a corridor public hearing has been held or the opportunity for such a hearing afforded. Id. IIt $6 \mathrm{a}, 10 \mathrm{~d}(1)(\mathrm{b}), 23$ C.F.R. at 13, 15. See also 23 U.S.C. \& 128 (1970).

12 FHWA Policy and Procedure Memorandum 20-8, đI 10d(2), 23 C.F.R. ch. I, pt. 1, app. A, at 16. A design public hearing must precede this approval. Id. If $6 \mathrm{a}, 10 \mathrm{~d}(2)$ (c), 23 C.F.R. at 13,16 . Under limited circumstances the location and design hearings may be combined. Id. If $6 \mathrm{~b}, 23$ C.F.R. at 13.

1323 U.S.C. $\S 106(a)$ (1970).

1423 C.F.R. $\$ 1.12$ (1972). Authorization to proceed at the construction phase is analogous to, but not to be confused with, authorization to proceed with federallysubsidized planning under $\$ 134$ of the Federal-Aid Highway Acts, discussed at text accompanying notes 50-66 infra.

15 FHWA Policy and Procedure Memorandum 90-1, $\Uparrow$ 6b (Aug. 24, 1971), reprinted in 2 ENv. L. REP. 46106, 46108 (1972).

$10 I d$. $f 6 \mathrm{c}$.

17 See note 12 supra. 
some circumstances a supplemental environmental impact statement must be prepared during design studies. ${ }^{18}$

Requiring only one full environmental inventory before "major Federal actions significantly affecting the quality of the human environment"19 are taken ignores the length and complexity of the planning process preceding most such actions. Because of the diverse elements and extended time involved in planning, no one impact statement, whenever it might be made, can satisfactorily meet the policy goals of NEPA. The Pennsylvania Department of Transportation (PennDOT) calculates that planning prior to construction of a section of highway, for example, covers several distinct phases and takes twelve years. ${ }^{20}$ Successive planning phases decrease in scope and increase in detail. For example, planning proceeds from a comprehensive transportation system analysis to consideration of a single section of highway, and from the study of alternative locations for a particular section to the consideration of design features such as culvert size and shape, placement of pedestrian crosswalks, and lighting. ${ }^{21}$

Even from this rough sketch, it should be clear that an environmental study undertaken at the system planning phase ${ }^{22}$ cannot consider the impacts of alternative design features which have not yet been conceived. By the same token, a study at the location or design phase is too late to deal appropriately with some of the broader impacts of, and alternatives to, ${ }^{23}$ a highway project or segment which is part

18 FHWA Policy and Procedure Memorandum 90-1, If 6p(1) (Aug. 24, 1971), reprinted in 2 ENv. L. REP. 46106, 46108 (1972).

The proposed Federal-Aid Highway Act of 1973, S. 502, 93d Cong., 1st Sess. (1973), could lead to the gradual disappearance of the complicated sequence outlined in the text. Section 134 of that bill would add $\$ \$ 171-76$ to title 23 . The new 23 U.S.C. $\$ 172(\mathrm{~b})$ would provide that

[a]ny State may submit to the Secretary for his approval and certification a comprehensive procedure for the construction of Federal-aid highway projects, setting forth the process by which such State proposes to carry out its Federal. aid highway construction responsibilities.

The proposed 23 U.S.C. \& $172(f)$ would provide that approval by the Secretary "shall discharge his responsibility under title 23 with respect to individual project approvals as required in chapter 1 of this title ...." Under the new $\$ 174(c)$, approval by the Secretary also would form "a contractual obligation of the Federal Government for the payment of its proportional contribution to all projects covered by the agreement," although the Secretary would continue to oversee projects and could withdraw his approval upon finding that the state has failed to observe the provisions of the agreement.

1942 U.S.C. $\$ 4332(2)(C)(1970)$.

20 Pennsylvania Dep't of Transportation, A New Highway is Born (undated).

21 The court in City of Boston v. Volpe likened phased highway planning to "an architect's plans, beginning with a broad conceptual rendering of a house in its setting and ending with detailed drawings of plumbing, outlets, and joists." 464 F.2d 254, 259 (1st Cir. 1972).

22 "System planning" and "planning at the system level" are used throughout this Comment as synonymous with "comprehensive planning" and may be rudimentarily defined as "[r]egional analysis of transportation needs and the identification of transportation corridors." FHWA Policy and Procedure Memorandum 90, II 3(e)(1), 37 Fed. Reg. 8398, 8399 (1972). Both terms are meant to encompass the determination of appropriate transportation modes within corridors.

${ }^{23}$ Section $102(2)(D)$, of NEPA requires all federal agencies to, "study, develop, 
of an integrated system. FHWA has recently acknowledged that many of the significant environmental effects of projects are determined at the system planning stage ${ }^{24}$ and that certain alternatives, mass transit in particular, are most effectively explored at that earlier stage. ${ }^{25}$

The Council on Environmental Quality (CEQ) ${ }^{28}$ has also recognized the weakness of much present environmental reporting. In a recent memorandum the $C E Q$ encouraged federal agencies responsible for impact reporting to focus on more broadly defined projects. Recommendation No. 9 of that memorandum stated:

In preparing statements, agencies should give careful attention to formulating an appropriate definition of the scope of the project that is the subject of the statement. In many cases, broad program statements will be appropriate, assessing the environmental effects of a number of individual actions on a given geographical area, or the overall impact of a large-scale program or chain of contemplated projects. ... Preparation of program statements in these cases should be in addition to preparation of subsequent statements on major individual actions wherever such actions have significant environmental impacts that were not fully evaluated in the program statement. ${ }^{27}$

Elsewhere the CEQ has explained that by affording an occasion for a more comprehensive consideration of effects and alternatives than is practicable in a statement on an individual action, a program impact statement can, under appropriate circumstances, serve what it perceives as the fundamental purpose of section 102(2)(C): "preventing unanticipated environmental effects from Government actions."

Thus, there is a need to begin considering environmental factors on a program level. It must be reemphasized, however, that environmental inventory at this stage cannot reveal all important impacts and

and describe appropriate alternatives to recommended courses of action in any proposal which involves unresolved conflicts concerning alternative uses of available resources ...." 42 U.S.C. $\$ 4332(2)$ (D) (1970).

24 Many significant economic, social, and environmental effects of a proposed project are difficult to anticipate at the system planning stage and become clear only during location and design studies. Conversely many significant environmental effects of a proposed project are set at the system's planning stage. Decisions at the system and project stages shall be made with consideration of their social, economic, environmental, and transportation effects to the extent possible at each stage.

FHWA Policy and Procedure Memorandum 90-4, If 14a, 37 Fed. Reg. 21430, 21432 (1972) (to be codified at 23 C.F.R. ch. I, pt. 1, app. A).

2534 Fed. Reg. 727 (1972) (discussion introducing adopted version of FHWA Policy and Procedure Memorandum 20-8).

26 CEQ was established by $\S 202$ of NEPA, 42 U.S.C. $\$ 4342$ (1970). Its duties and functions are defined by $\S 204$ of NEPA, 42 U.S.C. $\$ 4344$ (1970).

27 Council on Environmental Quality Memorandum to Federal Agencies on Procedures for Improving Environmental Impact Statements II B5, reprinted in 3 [Current Developments] BNA ENv. REP. 82, 87 (1972).

28 Third ANNUAL REPORT, supra note 2, at 231 . 
alternatives that may come to light after more detailed planning on a particular construction project. The need for environmental reporting at the project level remains.

\section{UNPROMISING ALteRNATIVES}

Given the need for a more comprehensive environmental assessment, two questions remain. First, at what point in the development of programs can overall environmental impact reporting most effectively further the fundamental purposes of section $102(2)(C)$ ? More significantly, what actions which come sufficiently early to serve this function are within section $102(2)(C)$ and thus require impact statements?

Two readily apparent possible occasions for broad-scope environmental reporting do not pass muster. The first such occasion is the submission of the state's annual highway construction program. It is unlikely that such programs, which are simply fiscal planning devices, could provide a satisfactory overview of related projects. The projects in any one year's program may bear a far less meaningful relation to each other than to projects in the programs of other years. This is caused by the structure of the grant-in-aid program under the FederalAid Highway Act which requires states to divide each long-range plan into annual segments for funding purposes. ${ }^{29}$

Equally unpromising as the occasion for a comprehensive section 102 statement is the state's submission of highway proposals for inclusion in one of several federal-aid systems. Each state engages in extensive fragmentation of projects at this point also, as it seeks places for priority items within the limits imposed by statute for additions to each of the federal-aid systems. ${ }^{30}$

Another alternative is to require system impact statements at the project location stage, requiring that the statement on each project, or at least on the first project within the system to reach location stage, address itself to the environmental ramifications of the system of which it is a part. Such a requirement might be inferred from NEPA in either of two ways: that the consideration of the impact of any single project

29 See Peterson \& Kennan, supra note 8, at 5004-05.

30 See 23 U.S.C. \& 103 (1970); 23 C.F.R. \& 1.6 (1972). A good example of fragmentation under the current federal-aid systems structure appears in the facts of Thompson $v$. Fugate, 347 F. Supp. 120 (E.D. Va. 1972). There, two-thirds of the Richmond beltway was made part of the federal interstate system. Lack of any remaining mileage on Virginia's interstate allocation prevented the inclusion of the rest of the beltway when it was proposed in 1968. Two years later, still short of interstate miles but anxious to complete the Richmond circumferential, the state resubmitted the last third of the beltway as part of the federal-aid primary system under the label of Route 288. As a result of these manipulations, what was essentially a single entity from the standpoint of planning wound up on the federal-aid network at two different times, as part of two different systems, and bearing two different route numbers. $C f$. Sierra Club v. Froehlke, 5 BNA ENv. REP. CAS. 1033, 1048 (S.D. Tex., Feb. 16, 1973) (numerous separately funded projects part of one program). 
is inadequate absent discussion that places it within its system context; or that the "action" referred to in NEPA was meant to encompass projected systems as well as the individual projects of which they are composed. ${ }^{31}$ The first argument is being made in at least two pending cases. $^{32}$ The second argument finds some support in cases such as Thompson v. Fugate, ${ }^{33}$ in which the court held that an impact statement was required under NEPA on an 8.3 mile segment of Route 288, which in turn was part of the 90 mile Richmond Beltway for which federal funds had not yet been requested by the state. In so holding the court stated that "[t]he beltway system must be viewed as a whole, and at the very least, Route 288 must be so viewed." 34 If the system must be viewed as a unit for the purpose of determining whether an impact statement should be prepared, logically it might also be considered a single action in determining the scope of the required statement or statements. ${ }^{35}$

This approach may be simply inadequate to achieve a sufficiently disinterested review of system plans in the highway context. An impact statement of any sort would not come, under present procedures, until just prior to location approval of the first highway project within the system. By then, however, if the state has sought some phase of program approval from the federal government, ${ }^{36}$ it will already have assigned a portion of its federal-aid systems allotment to accommodate the project (as well as other connected projects), ${ }^{37}$ and it will have placed itself under "a definite initial commitment ... to undertake and complete [the work of the phase programmed] within a reasonable length

31 This argument goes much farther than FHWA's expanded definition of a "highway section." FHWA Policy and Procedure Memorandum 90-1, III 3a, 6, reprinted in 2 ENV. L. REP. 46106 (1972); see Peterson \& Kennan, supra note 8, at 50017 \& n.86.

32 Indian Lookout Alliance v. Volpe, 345 F. Supp. 1167 (S.D. Iowa 1972), appeal docketed, No. 72-1620, 8th Cir., Sept. 29, 1972 ; Movement Against Destruction v. Volpe, Civil No. 72-1041M (D. Md., filed Oct. 10, 1972). This argument finds at least some support in those cases which have prohibited excessive segmenting of what is basically one highway as a means of limiting the scope of impact statements. See, e.g., Named Individual Members of San Antonio Conservation Soc'y v. Texas Highway Dep't, 446 F.2d 1013, 1023 (5th Cir. 1971), cert. denied, 406 U.S. 933 (1972); Committee To Stop Route 7 v. Volpe, 346 F. Supp. 731, 740 (D. Conn. 1972).

33347 F. Supp. 120 (E.D. Va. 1972). See note 30 supra.

34347 F. Supp. at 124. See Sierra Club v. Volpe, 4 BNA Evv. ReP. Cas. 1804 (N.D. Cal., Dec. 6, 1972); Named Individual Members of San Antonio Conservation Soc'y v. Texas Highway Dep't, 446 F.2d 1013 (5th Cir. 1971), cert. denied, 406 U.S. 933 (1972). But see Civic Improvement Comm. v. Volpe, 4 BNA ENv. REP. Cas. 1160 (W.DN.C.), aff'd, 459 F.2d 957 (4th Cir. 1972).

35 These arguments for system statements at the first project stage receive support from the recent decision in Sierra Club v. Froehlke, 5 BNA ENv. REP. CAS. 1033 (S.D. Tex., Feb. 16, 1973). That case held that if the dam involved was not primarily local in purpose, it must be considered as just one part of the river basin's comprehensive development program, and construction could not proceed without an impact statement on the broader project. Id. at 1054-55, 1060. Cf. Natural Resources Defense Council, Inc. v. Morton, 458 F.2d 827, 835 (D.C. Cir. 1972).

36 See note 10 supra.

3723 U.S.C. \$ 105 (1970). 
of time." ${ }^{\prime 38}$ If the funds for the programmed projects are not used for those projects they will be lost. ${ }^{30}$

Furthermore, local coordinating committees, decisionmaking bodies within the institutional forms which have grown to surround the "continuous planning process" of section $134(\mathrm{a}),{ }^{40}$ will have adopted at least that portion of a comprehensive plan on which the project is "based." Thus there will not be any truly independent determination of a regional comprehensive plan. In short, location approval of a particular project is not the proper occasion for a system impact statement because in most instances it will have been preceded by definite commitments, of funds and attitudes, on the part of state and local officials to implement the plan of which the project is a part.

Additionally, a combined impact statement on a project and the system of which it is a part could focus attention on one at the expense of the other. ${ }^{41}$ Careful and independent environmental analysis is needed for both the system and the individual projects. Nevertheless, requiring system impact statements at this stage could be valuable if administrators realize that it would be to their advantage (if only to avoid multiple assessments of system impacts as each project statement is prepared) to consider the combined environmental effects of the various projects within the comprehensive plan at the earlier, planning stage.

\section{Comiprehensive Transportation Planning}

It is not surprising that, unlike the impact statement requirement of NEPA, the pre-program comprehensive transportation planning required for urban centers by section 134(a) of title 23 has received little public attention. Under section 134(a) the Secretary of Transportation is directed not to issue program approval for projects

in any urban area of more than fifty thousand population unless he finds that such projects are based on a continuing comprehensive transportation planning process carried on cooperatively by States and local communities in conformance with the objectives stated in this section. ${ }^{42}$

38 Bureau of Public Roads, Policy and Procedure Memorandum 21-1, II 2 (Apr. 15, 1958), reprinted in 2 ENv. I. REP. 46507, 46508 (1972).

39 See Peterson \& Kennan, supra note 8, at 50005. At an earlier stage the funds could be transferred to another system being programmed. See id. 50004 .

40 See note 49 infra \& accompanying text.

41 See Brief for Appellees at 15, Indian Lookout Alliance v. Volpe, No. 72-1620 (8th Cir., filed Sept. 29, 1972).

4223 U.S.C. $\$ 134$ (a) (1970).

Procedures that have developed around \& 134(a) will form the basis of much of the discussion that follows in the text. An effort has been made to derive these procedures directly from relevant FHWA Policy and Procedure Memoranda (PPM's) and Instructional Memoranda (IM's). (For FHWA's explanation of the status of these memoranda, see 23 C.F.R. \$ 1.32 (1972).) In areas where PPM's and IM's seemed inconclusive or otherwise inadequate to resolve issues that arose, the existing administrative practices of 
It is at this comprehensive planning stage, before plans are broken up for inclusion in the federal-aid network and programmed for funding, and before interrelated planning on individual included projects rigidifies commitment to the plan, that there is the greatest potential for "more comprehensive consideration of effects and alternatives." though it is clear that the comprehensive planning stage is too early for impact statements concerning design features of future construction, it is equally clear that broad consideration of transportation modes and route location can be most useful at the time of the promulgation and later modification of urban transportation plans and system studies. These plans and studies are significant in that they typically contain planners' recommendations which are used to guide policy makers and programmers in their decisions. ${ }^{44}$

Two separate provisions in federal statutes, and their administrative interpretations, could require that environmental effects be considered at the comprehensive transportation planning phase. The central provisions are the impact statement requirement of section 102 (2) (C) of NEPA, and the recent Policy and Procedure Memorandum 90-4 promulgated by the FHWA in response to the Federal-Aid Highway Act of 1970.

\section{A. Impact Statements}

It is one thing to say that impact statements covering comprehensive transportation plans would further the fundamental purposes of section 102(2)(C). It is quite another to say that the preparation and adoption of such plans come within the meaning of that section, as federal courts have interpreted it, ${ }^{45}$ and require impact statements. It is now well established that for an environmental impact statement to be required three conditions must be met: the project must constitute a "federal action," be of "major" proportions, and significantly affect the quality of the human environment. ${ }^{46}$ Furthermore, the requirement of

the Pennsylvania Department of Transportation and FHWA Division Headquarters in Pennsylvania were used as references. These practices were ascertained in interviews with I.E. Keefer, Director, Bureau of Advance Planning, and J.B. Chiles, Director, Bureau of Programming, Pennsylvania Dep't of Transportation, in Harrisburg, Aug. 17, 1972, and R. Borg, Planning and Research Engineer, FHWA Division Headquarters, in Harrisburg, Sept. 8, 1972.

43 Third Anndar Reporx, supra note 2, at 233. See Letter from Russell Train, Chairman, Council on Environmental Quality, to John Volpe, Secretary of Transportation, Aug. 18, 1972.

44 Hearings on Urban Highway Planning, Location, and Design Before the Subcomm. on Roads of the Senate Comm. on Public Works, 90th Cong., 1st Sess., pt. 2, at 539 (1967); interview with L.E. Keefer, Director, Bureau of Advance Planning, Pennsylvania Dep't of Transportation, in Harrisburg, Aug 17, 1972.

45 As has been pointed out, "[t]he legislative history contains little discussion of the meaning of this phrase ['major Federal actions significantly affecting the quality of the human environment']." THIRD ANNOAL REPORT, supra note 2, at 231. This regrettable absence makes the development of interpretative case law indispensable in the effort to produce authoritative readings of $\S 102(2)(C)$ for the wide range of ongoing administrative activities to which it may apply.

4642 U.S.C. $\S 4332$ (C) (1970). 
impact statements, like other requirements of section 102, is applicable only "to the fullest extent possible." with these conditions it must be remembered that analogies must be relied upon, because no court has considered whether comprehensive planning under section 134 meets these requirements of NEPA's section 102.

\section{Federal Actions}

Under section 134, comprehensive planning is not done by FHWA, but by the state highway agency or a metropolitan or regional agency selected by the state. ${ }^{48}$ Plans and priorities are officially adopted and modified by committees composed of state highway officials and elected officials from affected political subdivisions, operating under the terms of written agreements between the state and the locality, to which the federal government is not a party. ${ }^{49}$ These arrangements require some justification for the assertion that section 134 planning can be considered "federal" within the meaning of NEPA's section 102(2)(C).

There is substantial support in recent judicial and administrative decisions for the conclusion that section 134(a) planning is federal for purposes of NEPA. Underlying this conclusion is the premise that federal contact with an action at its inception can sufficiently permeate what follows to imbue those acts with the necessary "federalness." Before developing this principle, it is necessary to outline the ways in which FHWA is involved in state highway planning decisions.

Section 307 (c)(2) of title $23^{50}$ sets aside $11 / 2$ percent of each state's yearly allocation of federal-aid highway funds for highway planning and research. ${ }^{51}$ These funds, abbreviated "HPR funds," may not be used for purposes other than planning and research. ${ }^{53}$ Another $1 / 2$ percent of the state's yearly allocation, commonly designated "PR funds," is available for planning and research if the state desires to use the money for that purpose rather than for preliminary engineering studies or construction. ${ }^{55}$ FHWA has sanctioned the use of HPR funds "for systematic and long-range planning and program-

47 Id. $\S 4332$.

48 Departatent of Housing and Urban Development \& Departatent of Transgortation, Report to the Congress on URBAN TRansportation POLICIEs, H.R. Doc. No. 92-331, 92d Cong., 2d Sess, 8 (1972).

4923 U.S.C. \& 134(a) (1970); FHWA Policy and Procedure Memorandum 50-9, II 4d (June 21, 1967); see Hearings on Urban Highway Planning, Location, and Design Before the Subcomm. on Roads of the Senate Comm. on Public Works, 90th Cong., 1st \& 2d Sess., pt. 2, at 538 (1968).

5023 U.S.C. $\S 307$ (c) (2) (1970).

51 Under most circumstances the state is required to match federal highway planning and research grants. $I d$. $\$ 307$ (c) (4).

52 FHWA Policy and Procedure Memorandum 50-1.1, đ 3b(1) (Apr. 18, 1972).

5323 U.S.C. \& 307 (c)(2) (1970).

54 FHWA Policy and Procedure Memorandum 50-1.1, đ 3b(2) (Apr. 18, 1972).

ธ5 23 U.S.C. $\S 307$ (c) (3) (1970). 
ming"56 and encourages their use in particular "for the development of comprehensive transportation plans in urban areas."

Under existing procedures, planning and research activities for which a state intends to seek reimbursement from section 307 funds are enumerated in an annual HPR-PR work program submitted by the state for FHWA approval. ${ }^{58}$ For administrative convenience the annual HPR-PR work program is treated as if it were "one project," although it covers a number of discrete planning items. ${ }^{60}$

Approval of the HPR-PR work program by FHWA does not represent a final commitment of section 307 funds for planning. Only FHWA "authorization to proceed" with the program or a particular portion of it establishes "the obligation of Federal funds." majority of urban planning projects, for which the work is to be done by a metropolitan or regional planning body rather than by the state highway agency itself, "authorization to proceed" is contingent on FHWA approval of the proposed contract or working agreement between the planning body and the state highway agency. ${ }^{62}$

Additional federal funds are available to state and metropolitan agencies under section 461 of title $40,{ }^{63}$ which specifically states that "[p]lanning which may be assisted under this section includes the preparation of comprehensive transportation surveys, studies, and plans ...."."64

In addition to its funding role, FHWA performs a formal supervisory function with regard to section 134 planning activities. FHWA administrative memoranda spell out the minimal content of an acceptable section 134 planning process ${ }^{65}$ and establish a pre-program "annual

56 FHWA Policy and Procedure Memorandum 21-3, I 7 a (Nov. 20, 1968), reprinted in 2 ENV. L. REP. 46515, 46516 (1972).

57 Id. If $7 \mathrm{a}(2), 2$ ENv. L. REP. 46516 . In addition to these sources, $\$ 114$ of the proposed Federal-Aid Highway Act of 1973, S. 502, 93d Cong., 1st Sess. (1973), would amend 23 U.S.C. $\S 104$ so as to authorize the Secretary of Transportation to apportion among the states up to $1 / 2$ per centum of annual Federal-aid system funds, "for the purpose of carrying out the requirements of section 134 of this title."

58 See, e.g., Pennsylvania Dep't of Transportation, Work Program H.P.R.-P.R.1(9) (1972).

59 FHWA Policy and Procedure Memorandum 50-1.1, I 8c (Apr. 18, 1972).

60 Among the items receiving detailed treatment in PennDOT's HPR-PR work program for fiscal year 1973 are comprehensive transportation activities not only in the state's 11 urban centers with populations over 50,000 but also in 6 centers with less than 50,000 people. See Pennsyivania Dep't of Transportation, supra note 58, at 35-47. PennDOT's HPR-PR document also outlines work on a statewide intermodal transportation plan. See id. 34 .

61 FHWA Policy and Procedure Memorandum 50-1.1, đ 8a (Apr. 18, 1972).

62 See id. โf 8b; FHWA Policy and Procedure Memorandum 50-1.2, đI 3 (May 18, 1972). PPM 50-1.2 goes on to spell out in great detail the provisions which must appear in such contracts or work agreements.

6340 U.S.C. \& 461 (1970).

64 Id. \& 461(a). Moneys allocated under this section are identified as $\S 701$ funds, although the original $\S 701$, Housing Act of 1954, ch. 649, § 701, 68 Stat. 590, did not specify that "comprehensive transportation surveys" were among the planning activities that it was intended to cover.

65 FHWA Policy and Procedure Memorandum 50-9 (June 21, 1967). 
certification procedure" under which planning activities in each of a state's urban areas must be warranted to comply with FHWA standards as a condition for program approval of projects in those areas. ${ }^{66}$ Certification does not in itself authorize "federal participation" either in the planning process or in the construction projects generated under a completed plan. It is merely a prerequisite for the allocation of construction funds to projects in the area, and no court has yet held that construction projects become federal for purposes of NEPA at any time before location approval. Nevertheless, the voluntary submission by states to federal planning standards and certification procedures indicates their intention to seek construction funds for the implementation of section 134 plans; it also enhances federal influence over the tenor of state planning efforts.

The recently decided case of Davis v. Morton ${ }^{67}$ serves as a starting point for the argument that comprehensive transportation planning is federal action for the purpose of applying NEPA's section 102(2)(C) impact statement requirement. In that case Pueblo Indians concluded a lease with a private land development company. The lease covered a 1300-acre tract with options on four other tracts of Indian land. A federal statute required the Secretary of the Interior to approve the lease before it could become effective, ${ }^{68}$ and he did so through his properly appointed delegate. When the lease approval was challenged, the court of appeals upheld the plaintiffs' position that the approval of the lease was a "major federal action" subject to the requirements of section $102(2)(\mathrm{C})$.

Clearly the approval itself was "federal action," just as the incremental funding of state planning activities is "federal action." In Davis, however, the government sought to draw a line between the approval of the lease, on the one hand, and the lease itself and subsequent development, on the other, just as one might be tempted to confine the characterization "federal" to periodic inputs of planning money and not extend it to the adoption of finished plans by local officials. The court capsulized the government's argument in Davis this way:

The United States did not initiate the lease, was not a party, possessed no interest in either the lease or the development, did not participate financially or benefit from the lease in any way. Before federal action will constitute major federal action under the mandates of NEPA, the government must initiate, participate in or benefit from the project. ${ }^{60}$

It was the court's view that the scope of federal participation

66 FHWA Instructional Memorandum 50-3-71 (Apr. 13, 1971).

67469 F.2d 593 (10th Cir. 1972).

0825 U.S.C. $\$ 415$ (a) (1970).

60469 F.2d at 595 . 
represented by the government's approval of the lease could not be confined to the mere approval of a piece of paper. Certain conditions in the lease (e.g., requirement of governmental approval of subsequent encumbrances on the leased lands; waiver of governmental liability for injuries on the leased lands) suggested to the court a governmental interest sufficient to make the lease and all that was contemplated by it federal. This broader view meant that the lease approval constituted "major federal action," only the effects of the lease, but also the effects of the projects which were to flow from that lease. ${ }^{71}$ There are, as has been discussed, ${ }^{72}$ numerous conditions in planning program agreements that indicate the federal government's active interest in the tenor and quality of the comprehensive planning efforts of state and regional planners. Under a Davis-type analysis, therefore, such interest could so pervade the entire "continuous planning process" as to render it, and the plans it produces, federal for purposes of section $102(2)(\mathrm{C})$.

Before developing this approach in the highway planning context, two differences should be noted. While the initial federal contact in Davis was the approval of a lease, the initial federal contact in highway planning is in the form of specific grants for such planning. And while an impact statement on what will result from the approval of the lease in Davis should be prepared at the time of that approval, the appropriate time for considering the environmental impact of what results from the planning funds is at the completion of the plans. ${ }^{73}$

There is more specific support for the conclusion that the injection of federal funds into the planning process makes the resulting plans federal for section 102(2)(C) purposes. Among actions that may trigger the section $102(2)$ (C) requirement, CEQ has included "[p]rojects and activities ... supported in whole or in part through Federal contracts, grants, subsidies, loans, or other forms of funding assistance."74 This formulation implies that programs ("continuing activi-

70 Id. at 596. But cf. Upper Pecos Ass'n v. Stans, 452 F.2d 1233 (10th Cir. 1971), vacated and remanded for a determination concerning mootness sub nom. Upper Pecos Ass'n v. Peterson, 409 U.S. 1021 (1972). In Upper Pecos Ass'n the county had received funds from the Economic Development Administration of the Department of Commerce for the construction of a road in an economically depressed area (pursuant to 42 U.S.C. $\$ \S 3121-226$ (1970). Plaintiffs unsuccessfully argued that the preparation of an impact statement by the Forest Service prior to location and design was meaningless since the grant had already been made. The lack of an intermediate planning action, and the direct, rather than complex, relationship among funding, planning, and construction, sharply differentiate this funding scheme from highway planning funding.

71 See 469 F.2d at 598.

72 Notes 50-66 supra \& accompanying text.

73 But cf. note 86 infra.

It must be remembered throughout this discussion that the argument being advanced is that federal funding makes the plans federal, not that the later building of roads based on these plans is federal if conducted without financial support. See note 82 infra.

74 Council on Environmental Quality Guidelines If 5(a) (ii), 36 Fed. Reg. 7724 (1971).

The Council's Guidelines were not promulgated as regulations. They may, however, carry great weight in judicial interpretation of the language of $\$ 102(2)(\mathrm{C})$ : 
ties") that receive federal funds but for which state and local officials retain primary responsibility may nevertheless be characterized as federal ${ }^{75}$ for purposes of NEPA.

This implication, that original federal funding so permeates the resulting program as to bring the results of that program within section $102(2)(C)$, has recently been given assertive force by several courts in a nonplanning context. Most significant is Named Individual Members of San Antonio Conservation Society v. Texas Highway Department. ${ }^{78}$ In San Antonio a multilane expressway through the Brackenridge-Olmos Parklands in San Antonio was broken into segments by the Texas Highway Department in the process of negotiating for FHWA approval over the objections of environmentalists. Two of the segments led up to the park on opposite sides, and the third, the disputed segment, sliced through the park to join them. The Secretary of Transportation "approved" the two segments outside the park in return for an agreement by the state to study alternative alignments between the two. State officials, however, declared their intention to build the middle segment with or without FHWA approval and the federal funds contingent on that approval. ${ }^{77}$ Despite the state's determination to go it alone on that segment if necessary, the court held that the entire expressway was a single project for purposes of determining the applicability of section $102(2)(\mathrm{C})$, and, most significantly for present purposes, that it had been subject to the requirements of section 102(2)(C) ever since the "Secretary of Transportation authorized federal participation." "T8 The state itself, as "a partner" in the

[W]e would not lightly suggest that the Council, entrusted with the responsibility of developing and recommending national policies "to foster and promote the improvement of environmental quality," has misconstrued NEPA.

Greene County Planning Bd. v. FPC, 455 F.2d 412, 421 (2d Cir.), cert. denied, 409 U.S. 849 (1972) (citation omitted).

75 The use of the term "federal" throughout this Comment is not meant to suggest that the activities are somehow not "state" activities at the same time. "Federal" is used in a restricted statutory sense to mark the extent to which courts may be willing to find $\S 102(2)(C)$ applicable to certain federal-state activities.

76446 F.2d 1013 (5th Cir. 1971), cert. denied, 406 U.S. 933 (1972).

San Antonio would be circumvented by a provision of the Federal-Aid Highway Act of 1973, S. 502, 92d Cong., 2d Sess. $\$ 147$ (1972), which states:

Notwithstanding any other provisions of Federal law or any court decision to the contrary, the contractual relationship between the Federal and State governments shall be ended with respect to all portions of the San Antonio North Expressway between Interstate Highway 35 and Interstate Loop 410, and the Expressway shall cease to be a Federal aid project.

The specificity of this provision indicates that it was written in an effort to alter the result of San Antonio without disturbing the legal basis on which the court reached that result; the Senate Public Works Committee has explained that such was its intention. S. Rep. No. 92-1081, 92d Cong., 2d Sess. 42-43 (1972). Consistent with this reading, criticism of the provision has not been that it undermines a judicial precedent but that it creates a Congressional precedent which will make it difficult for legislators to refuse subsequent state-requested exceptions of a similar nature. Trare, Oct. 9, 1972, at 62. The arguments that follow in the text, insofar as they are dependent on the continued vitality of San Antonio, assume the correctness of this reading.

77446 F.2d at 1027; see id. at 1017 \& n.7.

78 Id. at 1028. The court goes on to state: 
undertaking, was bound by those requirements. ${ }^{79}$ Thus San Antonio stands, at least in part, for the principle that authorization of federal participation in an enterprise is sufficient to make that enterprise federal for purposes of section $102(2)(\mathrm{C})$.

Subsequent discussion has characterized San Antonio as the federal judiciary's knee-jerk reaction to a peculiarly overt state attempt to evade federal law, which if allowed to go unchecked would seriously erode the law's ability to achieve its intended goals. ${ }^{80}$ But Thompson $v$. Fugate $^{81}$ indicates that San Antonio applies generally to federal-state relations under the Federal-Aid Highway Acts and NEPA, without regard to any intent to frustrate federal policy. Fugate, another highway case, considered a project which was a part of Route 288 , which was in turn a portion of the Richmond beltway; it had been planned to intersect Tuckahoe Plantation. Though the state department of highways had not yet applied for federal funds for the road in question, the court held that this project, as part of Route 288 and the beltway, other portions of which had already received substantial commitments of federal funds, was a federal action for purposes of section 102 (2) (C) and other federal statutes. The court's discussion in Fugate suggests, indeed, that this characterization was required, insofar as it could be supported by the facts, to prevent frustration of the congressional policy announced in NEPA. At the same time the opinion contains no indication that an intent to evade the requirements of NEPA underlay the state's delay in formally requesting federal-aid highway funds. The principle to be gleaned from San Antonio and Fugate is this: that after a state program has begun with federal approval and assistance, action pursuant to that program is federal and must conform with the requirements of NEPA. Noting the compelling nature of the congressional policies embodied in NEPA, the courts in both cases extended this principle to instances in which the state retained

That authorization triggered the advertisement for contract bids, the letting of contracts, and the commencement of construction that has erected almost $1 / 3$ of the southern "segment" of the North Expressway. No one forced the State to seek federal funding, to accept federal participation, or to commence construction of a federal aid highway. The State, by entering into this venture, voluntarily submitted itself to federal law. It entered with its eyes open, having more than adequate warning of the controversial nature of the project and of the applicable law. And while this marriage between the federal and state defendants seems to have been an unhappy one, it has produced an already huge concrete offspring whose existence it is impossible for us to ignore.

Id. at 1028.

79 This result was reached despite the fact that no federal funds had yet passed to the state. $I d$. at 1028.

80 Note, 50 Texas L. Rev. 381 (1972). See Civic Improvement Comm. v. Volpe, 4 BNA ENv. ReP. CAS. 1160 (W.D.N.C.), aff'd, 459 F.2d 957 (4th Cir. 1972) (a post-San Antonio case, in which, before concluding that an improvement was not a federal action under NEPA, the court felt compelled to note that the road's "widening with city funds only is not a device or subterfuge to evade environmental considerations," 4 BNA ENV. REP. CAS. at 1161).

81347 F. Supp. 120 (E.D. Va. 1972). 
or had attempted to retain the power to decide whether and in what form the activity would go to completion. ${ }^{82}$

If this principle is applied to section 134 planning operations, it should be clear that they are federal for section 102(2)(C) purposes once they have been included as items in an authorized HPR-PR program. At that time they have been fully reviewed at least twice by FHWA, and federal planning funds are committed. The federal nature of these planning activities is underscored by FHWA annual certification procedures, but certification is not essential: comprehensive planning for which certification is not required (i,e., statewide intermodal planning or comprehensive planning in urban areas of less than 50,000 ) is also federal under this reasoning, if it happens to have been identified as part of at least one HPR-PR program. ${ }^{83}$

One might also assert that a comprehensive transportation plan developed under section 134(a) becomes federal in light of a strong expectation that much of the plan will be implemented with federal funds at the construction phase. This assertion is subject to important qualifications, however. A state will not necessarily seek federal funds

82 In the foregoing cases, this conclusion was applied to portions of such a program; splitting off a portion from the main program did not divest it of its acquired "federalness." It has been pointed out that the court's holding in San Antonio was rather narrowly confined to the situation where one "project" was divided into "segments" for programming purposes. Note, 50 TExAS I. Rev. 381 (1972). Fugate has broken that confinement, it seems, for in that case the court held that Route 288 was in its entirety a federal action requiring an impact statement, although the route had been treated by the state as separate "projects" for programming purposes. The court in Fugate seemed on the verge of holding the entire beltway a single federal action, although such a step was not necessary to achieve its result:

The Richmond beltway, including Route 288 in its entirety, is indeed one which must be characterized as a major federal action and a proposed federally assisted undertaking. ...

The beltway system must be viewed as a whole, and at the very least, Route 288 must be so viewed.

347 F. Supp. at 123-24.

It should be noted at the same time, however, that neither San Antonio nor Fugale will comfortably support the contention that whole highway systems, portions of which have been or are being built with federal funds, are federal in every part for every purpose. This point was made by Civic Improvement Comm. v. Volpe, 4 BNA ENv. REP. CAS. 1160 (W.D.N.C.), aff'd, 459 F.2d 957 (4th Cir, 1972). Civic Improvement was a postSan Antonio decision in which it was beld that a locally funded street improvement was not federal, even though it connected with federally funded routes as part of a "sixth circumferential" and had been recommended in a 1960 comprehensive highway plan to whose development the federal government had contributed $\$ 91,000$. 459 F.2d at 959 (Craven, $J$., concurring and dissenting). This holding was not questioned by the court in Fugate, which distinguished the road at issue in Civic Improvement from the Tuckahoe portion of Route 288 as "an isolated street, local in nature." $347 \mathrm{~F}$. Supp. at 124.

It is unnecessary for this Comment to take a position on the permissible degree of "splitting." The argument here is that federal approval and funding of the state's planning process as a whole are sufficient to make that process federal under NEPA.

83 This result is not inconsistent with the one decision which has considered planning under $\& 102(2)(C)$. In deciding not to require an impact statement on Iowa's entire Statewide Freeway-Expressway System, the plan for which had been adopted in 1965, the court in Indian Lookout Alliance v. Volpe, 345 F. Supp. 1167 (S.D. Iowa 1972), relied, at least in part, on the fact that "[f]ederal approval has not been requested and is not needed for such planning. No federal money has been involved." $345 \mathrm{~F}$. Supp. at 1169. See text accompanying notes 104-11 infra. It is clear that these statements cannot be made with reference to planning done with $\$ 307(\mathrm{C})(2)$ funds. 
at the construction phase for every project which grows from section 134 (a) comprehensive planning activity. If a state does not seek federal funds, it is not obliged to follow the comprehensive plan $^{84}$ or to submit to other federal requirements, such as NEPA's section 102 (2) (C). It would seem to follow from this that no plan becomes federal simply by virtue of funds anticipated at the project development stage. Nevertheless, the general expectation of federal funds in implementation phases surely buttresses the characterization of section 134(a) comprehensive plans as "federal" and carries in addition the suggestion, developed below ${ }^{85}$ that such plans have substantial and immediate import for the preservation and enhancement of environmental values. ${ }^{80}$

84 Under $\$ \S 109-10$ of the proposed Federal-Aid Highway Act of 1973, S. 502, 93d Cong., 1st Sess. (1973), state designation of federal-aid primary and federal-aid urban highway systems would be required to be consistent with \$ 134 planning.

85 Notes 97-104 infra \& accompanying text.

86 An alternative view may be of some help if the "permeation" argument presented in the text is rejected. Even if the funds and guidance provided by the federal government are not sufficient to "federalize" the plans that result, the actual HPR-PR work program authorization might trigger the $\S 102(2)(C)$ requirement at that earlier stage. $C f$. notes 67-73 supra \& accompanying text. Authorization, the annual commitment of federal funds to state planning activities, is patently a federal action. The same may be said of the annual § 134 pre-program certification procedure. See D.C. Fed'n of Civic Ass'ns v. Volpe, 459 F.2d 1231, 1240 (D.C. Cir.), cert. denied, 405 U.S. 1030 (1972) (holding Dep't of Transportation could not delegate its certification responsibilities to the local planning agencies). Under the analysis presented in the text accompanying notes 87-94 infra, this authorization would be major. See Pennsyuvania Dep't of Transportation, supra note 58, at 10-11; Letter of Authorization from George F. Fenton, Division Engineer, FHWA, to Jacob Kassab, Secretary, Pennsylvania Dep't of Transportation, July 10, 1972. Similarly, if the argument is accepted that planning can significantly affect the quality of the human environment, see notes 95-109 infra \& accompanying text, then the FHWA's authorization will meet all of the $\$ 102(2)(C)$ criteria.

If an annual HPR-PR work program impact statement process were adopted, multiyear planning projects might be reviewed several times before their completion. The administrative burden imposed by this result would not be inconsiderable, although it could be reduced somewhat by granting less exhaustive treatment to aspects of planning items already dealt with in a previous year's impact statement. In spite of this burden, one federal court has required serial $\S 102$ (2) (C) statements on a single project funded under an annual appropriations arrangement. Environmental Defense Fund v. TVA, 339 F. Supp. 806 (E.D. Tenn. 1972) (TVA's yearly request for Congressional funds for the Tellico Project comes within the reach of $\$ 102(2)(C)$ and separate impact statements are required to accompany each appropriations request).

The efficacy of annual pre-program impact statements would be enhanced under an amendment to $\S 134(\mathrm{a})$ in the proposed Federal-Aid Highway Act of 1973, S. 502, 93d Cong., 1st Sess. (1973). This provision would direct the Secretary of Transportation to develop regulation for public participation in the $\S 134$ (a) process.

which shall include hearings, held at least annually, at which there would be a review of the transportation planning process, plans and programs, and opportunity provided for the consideration of alternative modes of transportation.

Id. $\S 124$. Whether public participation would be meaningful at this point might depend on assessments of systems alternatives available at the time of the hearings, If hearings were coordinated with existing HPR-PR work program review and certification procedures, an annual planning program impact statement might be available prior to hearings which could provide the basis for reasonably informed discussion of alternatives by participants. Nevertheless, it is not clear that incremental assessments of the activities of planning agencies within a state would fulfill all the purposes of environmental review at the systems phase. The desideratum remains a review of plans at a stage of completion that would allow full testing of each component in the context of the entire system. But $c f$. text accompanying notes 116-21 infra. 


\section{Major Actions}

The second requirement that must be met in order to bring an activity within section 102(2)(C) of NEPA is that it be "major." An essentially clear and readily applied test for this quality was propounded by the court in Natural Resources Defense Council v. Grant, ${ }^{88}$ and has subsequently found general approval.89

Grant defined a major action as a "federal action that requires substantial planning, time, resources, or expenditure." Tho Chicod Creek Watershed Project, found to be "major" by the Grant court, took "several years" of planning and preparation, and cost $\$ 1,503,831$, of which $\$ 706,684$ was budgeted from federal sources.

Under Grant, the preparation of comprehensive plans in major urban areas clearly represents a "major" governmental effort for purposes of section 102(2)(C). An areawide network planning study in an urban context may take five years to complete ${ }^{21}$ and require updating at regular intervals after its completion. A study in a city such as Philadelphia could easily cost the federal government $\$ 3,000,000,{ }^{92}$ an expenditure nearly three times the Soil Conservation Service's commitment to the Chicod Creek project. While planning for smaller urban areas will undoubtedly cost less, it is clear that in all section 134 planning significant outlays of federal money are involved, at least on the order of magnitude of the expenditures in Grant.$^{33}$ Furthermore, the

8742 U.S.C. $\$ 4332(2)$ (C) (1970).

88341 F. Supp. 356 (E.D.N.C. 1972).

89 See, e.g., Hanly v. Mitchell, 460 F.2d 640, 644 (2d Cir.), cert. denied, 409 U.S. 990 (1972); THIRD ANNUAL REPORT, supra note 2, at 231 n.62.

00341 F. Supp. at 366-67.

91 Pennsylvania Dep't of Transportation, supra note 20.

02 Because the cost of an activity of this scope and duration would be met from several sources and spread over several fiscal periods, it may not be readily determinable. Pennsylvania's HPR-PR program for fiscal year 1973 calls for a total expenditure of $\$ 8,143,390$, of which $\$ 4,790,935$ or about $59 \%$ is authorized as the federal share. Letter of Authorization from George F. Fenton, Division Engineer, FHWA, to Jacob Kassab, Secretary, Pennsylvania Department of Transportation, July 10, 1972. The work program puts the cost of carrying on the continuous transportation planning process in Philadelphia at $\$ 1,029,400$, which represents a federal expenditure of over $\$ 600,000$, if it is assumed that the ratio of federal to state funds allocated for planning in Philadelphia is the same as the ratio for the HPR-PR project for the entire state. An equivalent expenditure over five years yields the $\$ 3,000,000$ figure in the text. This figure represents only funds from federal-aid highway sources; input of federal funds from other sources is treated in the text accompanying notes 63-64 supra.

93 Furthermore, to the extent the exact figures are significant, there is support for the view that in determining whether an action is "major" for $\$ 102(2)$ (C) purposes it is proper to look at the entire amount spent for the action, not just the amount of federal money spent. For example, in licensing cases "major federal actions" are found despite the fact that no federal money will be spent on the project, thereby indicating that the conclusion that an action is "federal" and that it is "major" are totally unrelated. See, e.g., Davis v. Morton, 469 F.2d 593 (10th Cir. 1972) (approval of lease of Indian land); Greene County Planning Bd. v. FPC, 455 F.2d 412 (2d Cir.), cert. denied, 409 U.S. 849 (1972) (undisputed); Izaak Walton League of America v. Schlesinger, 337 F. Supp. 287 (D.D.C. 1971) (AEC interim operating license for nuclear power plant). Thus in determining whether $\$ 134$ (a) planning is major, both state and federal money should be considered. Except under limited circumstances, states are required to match federal planning contributions. See note 51 supra \& accompanying text. 
periodic revisions of these comprehensive plans are also sufficiently major to come within the impact statement requirement. Each individual revision, whatever the cost, is under the larger umbrella of comprehensive planning, which, as a whole, even after the adoption of the original plan, requires significant amounts of time, effort, and money. Splitting the planning process into segments which would avoid their classification as "major actions" is no more justified than separating highway segments to avoid the "federal" label. ${ }^{.4}$

\section{Actions Significantly Affecting the Quality of the Human Environment}

The fact that an action is "major" does not necessarily imply that it significantly affects the quality of the human environment. ${ }^{95}$ That last portion of the section 102(2)(C) formula was construed by the Grant court as applying to actions "having an important or meaningful effect, direct or indirect, upon a broad range of aspects of the human environment." ${ }^{\text {"Is }}$ In considering this definition it must be remembered that by its nature the effect of a plan can only be indirect, and, of course, whether it has any impact will depend on its implementation. It must be expected that not all of the steps recommended by planners at the systems stage will be taken, and not all of the steps taken pursuant to an adopted plan will be federally funded or otherwise involve FHWA. ${ }^{97}$ Once they are adopted, however, comprehensive plans exert a controlling influence because construction projects for which a state expects federal funds must be consistent with the section 134 (a) plans. ${ }^{98}$ Furthermore, spurred by the addition of section 109(h) to the highway code, ${ }^{99}$ FHWA has recently encouraged states to produce plans for bringing programs into closer accord with comprehensive studies and objectives. ${ }^{100}$ This new initiative supports an expectation that completed

84 See, e.g., Indian Lookout Alliance v. Volpe, 345 F. Supp. 1167 (S.D. Iowa 1972); Named Individual Members of San Antonio Conservation Soc'y v. Texas Highway Dep't, 446 F.2d 1013 (5th Cir. 1971), cert. denied, 406 U.S. 933 (1972).

${ }^{95}$ Hanly v. Mitchell, 460 F.2d 640, 644 (2d Cir.), cert. denied, 409 U.S. 990 (1972).

96341 F. Supp. at 367 .

97 See Civic Improvement Comm. v. Volpe, 4 BNA Env. ReP. Cas. 1160 (W.D.N.C.), $a f ' d, 459$ F.2d 957 (4th Cir. 1972).

98 FHWA Instructional Memorandum 50-3-71, đ B2 (Apr. 13, 1971) (implementing 23 U.S.C. $\$ 134(1970))$.

9923 U.S.C. \& 109 (h) (1970).

100 FHWA Policy and Procedure Memorandum 90-4 II 14b(2), 37 Fed. Reg. 21430, 21432 (1972) (to be codified at 23 C.F.R. ch. I, pt. 1, app. A). The "action plans" required by PPM 90-4 are discussed at text accompanying notes 122-33 infra. Two factors which in the Department of Transportation's view have inhibited implementation of "complementary transportation plans" were spelled out in the 1970 Highway Needs Report:

First, imaginative coordinated programs are often not implemented because the funds required for the public transportation portions of complementary schemes have not been available at the time needed .... Second, most planning agencies do not have the authority to implement plans. A plan, once developed, is turned over to one or more of the many fragmented units of local government for imple- 
plans will become more fully determinative of the pattern of construction that follows their adoption, enhancing their significance in terms of eventual impact on "the quality of the human environment."

In order to conclude that comprehensive system plans require impact statements it is necessary to overcome the notion that only practical developments-construction and other physical disturbances -can significantly affect the quality of the human environment and trigger section $102(2)$ (C). Such an attitude would directly contravene the clear implication of the Grant test that significant impacts can be indirect. More basically, this attitude is refuted by the very words of section $102(2)(C)$. That section requires impact statements "on proposals for legislation and other major Federal actions significantly affecting the quality of the human environment."101 This clearly implies that legislation is one form of action that can significantly affect the environment. Thus the phrase cannot be read as including only construction and other physical developments. Clearly a comprehensive plan with which future construction must be consistent will often have a far more direct environmental impact than legislation.

Similarly, it is not impossible or unrealistic to have significant and worthwhile statements at the planning stage. For example, FHWA has filed an impact statement on a policy and procedure memorandum which does no more than require states to develop procedures to guaran-

mentation. These governmental units frequently fail to coordinate their efforts to

the degree necessary to effectively implement the plan.

Federal Higenway Adaimistration, U.S. Departament of Transportation, 1970 NaTTONAL Highway NeEds Report 16 (prelim. ed. 1970).

Corrections to overcome these problems are still to be made at the state and local levels in many areas. At the federal level, some corrective measures appear in the proposed Federal-Aid Highway Act of 1973, S. 502, 93d Cong., 1st Sess. (1973). As amended and approved by the Senate, it would partially remove the "for-highways-only" tag on federal-aid highway funds. 119 Covg. Rec. 54746-82 (daily ed. Mar. 14, 1973). The bill also contains a provision which would encourage the development of the "metropolitan transportation agency." Id. \& 125(a) (proposed amendment to 23 U.S.C. \& 135 (1970)). A creature of local governments within a single urban region, the metropolitan transportation agency would have "sufficient authority to develop and implement a plan for expenditure of funds ...."Id. The bill would encourage the growth of such organs by making them prospective recipients of federal-aid funds for the urban system. The coordinated region-wide expenditure of these funds for transportation, if competently administered, should correct, at least to some degree, the fitfulness with which past plans have been implemented.

Should they be enacted (as of this writing the amendment had passed the Senate, 119 Cons. REc. 54982 (daily ed. Mar. 15, 1973), but failed in the House, N.Y. Times, Apr. 20, 1973, at 1, col. 2) both of these developments would enforce the point made in the text: that plans may be expected to have greater and greater impact in terms of the pattern of construction which follows their adoption.

101 The actual language of $\$ 102(2)(C)$ requires agencies to "include in every recommendation or report on proposals for legislation and other major Federal actions significantly affecting the quality of the human environment, a detailed statement . . . "42 U.S.C. \$ 4332(2)(C) (1970). Arguably, \& 134(a) plans would fall within this language as being "recommendation[s] or report [s] on proposals for ... major Federal actions significantly affecting the quality of the human environment," since the projects they recommend clearly are within $\S 102(2)(\mathrm{C})$. This argument would make much of the textual analysis unnecessary for the conclusion, but the courts have apparently ignored the "recommendation or report" language in their construction of the statute. 
tee input by interested parties, ${ }^{102}$ a far less specific determination than a comprehensive plan. This is not to say that further impact statements will not be needed at a later stage when location or design decisions are made. ${ }^{103}$ Decisions at more than one level can constitute "actions significantly affecting the quality of the human environment."

One recent district court decision raises questions concerning several of the propositions developed thus far in this Comment. In Indian Lookout Alliance v. Volpe ${ }^{104}$ the plaintiffs sought, among other things, an environmental impact statement on Iowa's entire Freeway-Expressway System, and on one particular 272-mile freeway within that system. The plans for the system had been adopted by the state highway commissioner in 1965. ${ }^{105}$ The court held that no impact statement was required. Speaking of the Freeway-Expressway System and the one freeway involved, the court stated:

These are nothing more than tentative plans for future highway construction for at least 20 years. The map introduced as an exhibit shows only general corridors which are subject to change. Federal approval has not been requested and is not needed for such planning. No federal money has been involved. Neither has reached the stage of being a "major federal action." 106

The conclusion that a "major federal action" was not involved apparently resulted from the lack of federal approval or money-a conclusion which does not present difficulties as to planning that is federally funded under section $307 .^{107}$ To the extent, however, that the court was influenced by the tentative nature of these plans, the opinion is inconsistent with the present analysis. This concern cannot be related to the question whether the plans were "federal." Nor is the concern over tentativeness related to the question of whether the action involved was major. Rather, to the extent the plan's tentative nature was given weight by the court, it must have been because of the court's belief that a plan cannot have a significant effect on the environment - thus failing under the third section 102(2)(C) criterion, unmentioned by the court. ${ }^{108}$ As has been discussed, such a conclu-

102 Federal Highway Administration, U.S. Dep't of Transportation, Firai EnVIRONMTENTAL IMPact Statement on 109(h) Gumedines (1972) (National Technical Information Service No. EIS AA 724994 F).

103 See text accompanying notes 22-38 supra.

104345 F. Supp. 1167 (S.D. Iowa 1972).

$105 \mathrm{Id}$. at $1168-69$.

108 Id. at 1169.

107 See notes 50-60 supra \& accompanying text.

108 At least one other court has apparently considered the tentative nature of an action relevant to the "major federal action" requirement, rather than the appropriate "significantly affecting the quality of the human environment" language. See Upper Pecos Ass'n v. Stans, 452 F.2d 1233 (10th Cir. 1971), vacated and remanded for a determination concerning mootness sub nom. Upper Pecos Ass'n v. Peterson, 409 U.S. 1021 (1972). 
sion is unjustified in view of the influence section 134 plans exert over later projects. ${ }^{109}$

\section{Possibility and Practicality}

The Indian Lookout court impliedly raised another problem: the requirements of section 102 of NEPA, including impact statements, apply only "to the fullest extent possible."110 Speaking of the plan, the court said "[i]t would be impossible to prepare an [environmental impact statement] on such indefinite proposals and it would be highly impractical to require it."111 In making this statement the court made no reference to the "fullest extent possible" language of the act but that is the only conceivable basis for its concern with possibility and practicality. Admittedly, by virtue of their very scope and their remoteness in time from project construction, comprehensive plans must be general and tentative. It is precisely these qualities which make the comprehensive planning phase most appropriate for evaluating broad impacts and alternatives before commitments to individual projects have been made, and while elements of the system can still be readily adjusted to compensate for changes on the system level. These qualities do not make impact statements on section 134(a) plans impossible or even impractical. As to the latter, it has been well established by the courts that inconvenience does not excuse the impact statement requirement. ${ }^{112}$ And any claim of impossibility must be viewed in light of the legislative history which indicates that the phrase "to the fullest extent possible" was meant to expand rather than limit the obligations of federal agencies, requiring compliance with section 102 (2) "unless the existing law applicable to such agency's operations expressly prohibits or makes full compliance with one of the directives impossible ...." N13 No statute limits the FHWA's obligations in this regard. Furthermore, both the FHWA ${ }^{114}$ and the

109 The court's objections to requiring an environmental impact statement on the plan for the entire system do not appear to have included the plan's having been adopted prior to the effective date of NEPA, Jan. 1, 1970. This omission suggests that the court failed to consider the plan an action separate from its possible later implementation.

11042 U.S.C. $\$ 4332(2)$ (C) (1970).

111345 F. Supp. at 1169-70.

112 See, e.g., Calvert Cliff' Coordinating Comm., Inc. v. United States AEC, 449 F.2d 1109, 1115 (D.C. Cir. 1971) ("Thus the Section 102 duties are not inherently flexible .... Considerations of administrative difficulty, delay or economic cost will not suffice to strip the section of its fundamental importance.").

113 Conference Report No. 91-765, 91st Cong., 1st Sess. 9 (1969); see Council on Environmental Quality Guidelines II 4, 36 Fed. Reg. 7724 (1971) (adopting this interpretation); City of New York v. United States, 337 F. Supp. 150, 158 n.9 (E.D.N.Y. 1972). The Conference Report expressed the intention that "no agency shall utilize an excessively narrow construction of its existing statutory authorizations to avoid compliance." Conference Report No. 91-765, 91st Cong., 1st Sess., 10 (1969).

114 The FHWA has recently agreed to prepare a "regional impact consideration" for the 3-A system in Baltimore. Among the issues scheduled for discussion in the consideration are the "[c]umulative (Regional) air pollution impact of the various stages of completion of the currently envisioned 3-A system" and "[a] detailed discussion of possible modification to the proposed system to mitigate air pollution problems." Memorandum 
Environmental Protection Agency ${ }^{115}$ have indirectly indicated that program impact statements are in fact feasible.

\section{Planning or a Plan}

Under one set of circumstances even the completion of a comprehensive plan could be too late for an effective systems impact statement. In D.C. Federation of Civil Associations v. Volpe ${ }^{116}$ the district court held that under the language of section 134(a) a highway project in an urban area need not be part of a completed transportation plan for the area. It need only grow from an acceptable planning process. ${ }^{117}$ Although the court did not rely on it, there is support for this position in the legislative history. ${ }^{118}$

Thus, unless a periodic review of in-process planning is required, ${ }^{119}$ important projects might be able to avoid section 134(a) systems impact statements by reaching advanced stages before a fullplan review became possible. This danger is limited by two facts. First, the court of appeals in D.C. Federation, though reversing on other grounds, substantially undercut the district court's holding on this point by stating that the Department of Transportation must take "into account the recommendations of local plans . . .."120 Second, since the time of the D.C. Federation decision the FHWA has stated that it will not grant program approval to any project in an urbanized area unless the project "serves to implement an areawide

from J. Collins, Transportation Coordinator, Environmental Impact Branch, Region III, Environmental Protection Agency, to J. Canny, Dep't of Transportation, Sept. 15, 1972. Impacts and alternatives relating to land use and urban societal patterns could also be successfully addressed in a program $\$ 102$ statement. See note 24 supra. It should, however, be noted that the quoted agreement was in the nature of a compromise, and the required "regional impact consideration" is not a full impact statement in either its scope or its review process. See Letter from John C. Armor to the University of Pentusylvania Law Review, Dec. 20, 1972, on file in Biddle Law Library, Univ. of Pa. Law School.

115 See Letter from Paul De Falco, Jr., Regional Administrator, Region IX, Environmental Protection Agency, to Regional Administrator, Region IX, Federal Highway Administration (undated), reprinted in Brief for Appellant at A-1, Indian Lookout Alliance v. Volpe, No. 72-1620 (8th Cir., filed Dec. 8, 1972); Letter from Bart Hague, Chief, Environmental Impact Branch, Region I, Environmental Protection Agency, to Angelo J. Siccardi, Division Engineer, Federal Highway Administration (May 1, 1972), reprinted in Brief for Appellant at A-7, Indian Lookout Alliance v. Volpe, No. 72-1620 (8th Cir., filed Dec. 8, 1972).

116316 F. Supp. 754 (D.D.C. 1970), rev'd on other grounds, 459 F.2d 1231 (D.C.

Cir. 1971), cert. denied, 405 U.S. 1030 (1972).

117316 F. Supp. at 795.

118 The Committee recognizes that transportation planning is almost invariably a continuing process; hence, this section has been drawn in such a way as to make it clear that a completed comprehensive plan, as such, is not necessary to meet its requirements.

S. Rep. No. 1997, 87th Cong., 2d Sess. 25 (1962).

119 See note 86 supra.

120459 F.2d 1231, 1240 (D.C. Cir. 1972). The court also stated that, "[n]o comprehensive transportation plan had been adopted at that time," and referred to the local planning commission approval as "stale, inapposite, and unsupported by any underlying, comprehensive plan ...." Id. at 1241 . 
plan developed within the planning process and held currently valid by the policy board." 121

\section{B. Other Statutory Provisions}

NEPA contains, in addition to the "action-forcing" section 102 $(2)(C)$, language directing federal agencies "to the fullest extent possible" generally to make creative use of "the policies, regulations, and public laws of the United States" in an effort to achieve the Act's broad goal of environmentally sound planning on a national scale. ${ }^{122}$ Congress has redirected this mandate to FHWA in quite specific terms. The Federal-Aid Highway Act of 1970 required the Secretary of Transportation to

promulgate guidelines designed to assure that possible adverse economic, social, and environmental effects relating to any proposed project on any Federal-aid system have been fully considered in developing such project . . . . ${ }^{123}$

The Secretary's response, Policy and Procedure Memorandum 90-4 (PPM 90-4), was adopted on October 1, 1972.124 It requires each state intending to participate in federal-aid funds to submit, by June 15, 1973, an action plan for integrating the considerations spelled out in section 109(h) into the state agency's structure and procedures. ${ }^{125}$

An action plan should explain

[p]rocedures to be followed to: (a) Insure that potential social, economic, and environmental effects are identified insofar as practicable in system planning studies as well as in later stages of location and design. ${ }^{126}$

PPM 90-4 further requires "procedures to be followed to insure that ... [a] range of alternatives appropriate to the stage is considered at each stage from systems studies through final design."127 If the procedures developed under these provisions are adequate, the resulting assessment should not be very different from what would be contained in a section $102(2)(C)$ statement. There should even be a close approximation of the section $102(2)$ (C) requirement that a draft

121 FHWA Instructional Memorandum 50-3-71, II B2 (Apr. 13, 1971).

12242 U.S.C. $\$ 4332$ (1) (1970).

12323 U.S.C. \$ 109 (h) (1970).

12437 Fed. Reg. 21430 (1972) (to be codified at 23 C.F.R. ch. I, pt. 1, App. A).

125 "The FHWA will not give location approval on projects after November 1, 1973, unless the Action Plan has been approved." FHWA Policy and Procedure Memorandum 90-4, I 6f, 37 Fed. Reg. 21430, 21431 (1972). "The FHWA may withhold location approvals, or such other project approvals as it deems appropriate, if the Action Plan is not being followed." Id. 【 7a, 37 Fed. Reg. 21431.

120 Id. II 14b, 37 Fed. Reg. 21432.

127 Id. If $10 \mathrm{~b}(2)$, 37 Fed. Reg. 21432. 
impact statement be circulated for the comments of "any Federal agency which has jurisdiction by law or special expertise with respect to any environmental impact involved ${ }^{\prime 128}$ and that it be made available to the public. ${ }^{129}$ PPM 90-4 provides that "[i]nformation about the existence, status, and results of studies should be made available to the public throughout those studies." 130 It also declares as a matter of policy that "[o]ther agencies" as well as the public should be "involved in project development early enough to influence ... final decisions." 131 It requires specifically that states develop procedures

$[t] o$ insure that interested parties, including local governments and metropolitan, regional, State and Federal agencies, and the public have an opportunity to participate in an open exchange of views throughout the stages of project development. $^{132}$

Although a crabbed reading of "project" could confine the reach of this provision to location and design phases, it should be clear from the statement of FHWA in first proposing PPM 90-4 that it is intended to include interagency review procedures at the regional planning stage as well. The FHWA stated: "Other governmental agencies and the public must be fully informed of highway planning and their views solicited and considered at all phases of the highway planning procedure."133

Thus the provisions of PPM 90-4 could serve as the basis for a de facto impact statement procedure at the system stage, under which analyses of system impact and alternatives would be available for comment to all interested parties: agencies with special expertise as well as members of the lay public. Whether such an arrangement actually develops, of course, will depend on the exact content of the action plans submitted by states under PPM 90-4.

\section{CONCLUSION}

The highway decisionmaking process is too long, and its varied components too complex, to permit thorough environmental analyses

12842 U.S.C. $\$ 4332(2)(C)$ (1970).

$129 \mathrm{Id}$.

130 FHWA Policy and Procedure Memorandum 90-4, ๆ 11a, 37 Fed. Reg. 21432 (1972).

131 Id. đI $4 \mathrm{~b}(2), 37$ Fed. Reg. 21431.

132 Id. I $11 \mathrm{~b}(2), 37$ Fed. Reg. 21432.

13337 Fed. Reg. 8398 (1972) (emphasis added).

The FHWA also stated that

[t]he action plan adopted by each State will require the early identification of economic, social and environmental effects to permit complete analysis and consideration while alternatives are being formulated and evaluated. The plan will also require the involvement of other governmental agencies and the public early enough to influence both technical studies and final decisions of the plan, and Id. will require full consideration of reasonable alternatives. 
at any single point in time. "Compliance to the 'fullest' possible extent would seem to demand that environmental issues be considered at every important stage in the decision making process ...."134 Arguments can be made that would require environmental impact statements to be written at many procedural junctures. To require statements at all such points would be both duplicative and unrealistic.

The very profusion of potential triggering events may give DOT and FHWA a certain flexibility in choosing the points at which section 102 (2) (C) should apply. But at some point fundamental questions concerning the environmental effects of regional transportation development must be asked. Meaningful consideration must be given to alternative transportation modes and the interrelationships of individual projects.

This Comment has discussed possible times for such consideration, and, based on considerations of policy and law, has urged that one-the completion of a comprehensive plan-be selected. But to a great extent the actual choice must lie with the agencies involved. ${ }^{135}$ Hopefully, the choices made will be consistent not only with their own goals and internal capabilities, but also with the purposes of NEPA and the tenets of enlightened planning policy. In any event, the agencies must not be allowed to escape the burden of considering at some point the overall impact of transportation development.

134 Calvert Cliffs' Coordinating Comm., Inc. v. United States AEC, 449 F.2d 1109, 1118 (D.C. Cir. 1971). Although Judge Wright was referring to the various stages of review concerning one decision, the language is equally applicable to decisionmaking over time. See Upper Pecos Ass'n v. Stans, 452 F.2d 1233, 1237 (10th Cir. 1971) (Murrah, J., dissenting), cert. granted sub nom. Upper Pecos Ass'n v. Peterson, 406 U.S. 944, vacated and remanded for a determination concerning mootness sub nom. Upper Pecos Ass'n v. Peterson, 409 U.S. 1021 (1972).

135 Explorations which should lead to such agency choices in the transportation systems planning field are now under way. Letter from Russell Train, Chairman, Council on Environmental Quality, to John Volpe, Secretary of Transportation, Aug. 18, 1972. 